\title{
Opportunistic Cyanobacteria in benthic microbial mats of a tropical lagoon, Tikehau Atoll, Tuamotu Archipelago: minor in natural populations, major in cultures
}

\author{
Katarzyna A. Palińska ${ }^{1}$, Raeid M. M. Abed ${ }^{2 *}$, Katja WendT ${ }^{1}$, Loic CharpY ${ }^{3}$, Maria \\ ŁотоскA ${ }^{4} \&$ Stjepko GoluBic ${ }^{5}$
}

\author{
${ }^{1} \mathrm{IBU}$, CvO University of Oldenburg, D-26111 Oldenburg, Germany \\ ${ }^{2}$ College of Science, Biology Department, Sultan Qaboos University, Al-khoud, Muscat, Sultanate of Oman; \\ "corresponding author e-mail: rabed@squ.edu.om; tel.: +968-92867442, fax: +968-24141347 \\ ${ }^{3}$ IRD, CNRS, Université Méditerranée, UMR LOPB MIO, F-13288 Marseille, France \\ ${ }^{4}$ Institute of Oceanology, Polish Academy of Sciences, PL-81-712 Sopot, Poland \\ ${ }^{5}$ Biological Science Center, Boston University, 5 Cummington street, Boston, MA 02215, USA
}

\begin{abstract}
Studies in microbial ecology focus on identifying field dominant microbial populations using culture-independent tools, whereas minor populations are often ignored. We characterized the cyanobacterial populations from the Tikehau Atoll lagoon, Tuamotu Archipelago, which responded to standard culturing media. The cultivation approach recruited cryptic cyanobacterial taxa, which were not observed in the studied mats, as revealed by microscopic comparison. Twelve strains belonging to the unicellular genera (Aphanothece NäGELI, Chlorogloea WILLE and Cyanocystis BorzI) and the filamentous cyanobacteria with narrow filaments (Leptolyngbya Anagnostidis et Komárek, Phormidium Küzing ex Gomont and Pseudanabaena Lauterborn) dominated the cultures. The genera Cyanocystis and Chlorogloea were genotypically characterized for the first time. Four strains assigned to Phormidium showed 100\% identity using 16 S rRNA sequences but additional gene analyses as well as phenotypic distinctions suggest finer differentiation within this group. Eight cyanobacterial strains out of twelve fixed dinitrogen with rates ranging from 3.3 up to 15.8 nmoles $\mathrm{N}_{2} \mu \mathrm{g}^{-1} \mathrm{Chl}-a \mathrm{~h}^{-1}$ and their nitrogen fixation ability was further confirmed by molecular detection of nifH gene. Nine strains possessed phycoerythrin, and two performed complementary chromatic adaptation. The present study documented the existence of an autochthonous subdominant cyanobacterial assemblage with variable physiological features that may enable them to replace dominant species in the microbial mats of Tikehau Atoll lagoon. These minor populations may be ecologically important, particularily in case of environmental disturbances.
\end{abstract}

Key words: Autochthonous, benthos, cyanobacteria, polyphasic approach, nifH, 16S rRNA

\section{Introduction}

Marine benthic cyanobacteria are the principal primary producers and builders of biofilms, microbial mats, microbialites, stromatolites and other organo-sedimentary structures with long geological history (Golubic et al. 2000). Microbial mats are common in subtidal ranges of coral reefs and tropical lagoons (SPRACHTA et al. 2001; ABED et al. 2003). Under normal oligotrophic conditions, diverse cyanobacterial populations occupy scattered denuded surfaces in the reef or form colonies and localized benthic mini-blooms (ABED et al. 2003a, b). Yet, in recent years, massive benthic blooms of mat-forming and often toxic cyanobacteria occur with increasing frequency in coral reefs and tropical lagoons in response to natural and man-made environmental disturbances (PAUL et al. 2005; LitTLER et al. 2006; LAURENT et al. 2008). The nature and identity of these cryptic cyanobacterial species have not been resolved.

Culture-independent molecular methods applied in microbial ecology have achieved major progress, however, these approaches bring their own limitations, such as selectivity in differential cell lysis, DNA extraction efficiency (e.g. depending on robustness of cell walls, presence of exopolymers, osmotic status), primer selectivity, and PCR biases (RAVEnschlag et al. 
1999). Cultivation of microorganisms, on the other hand, although central to bacteriological tradition and essential for studying physiological, biochemical and genetic properties of individual microorganisms, is known to underestimate the real diversity of bacterial communities in nature (Amann et al. 1995; Delong \& Pace 2001). Axenic strains represent only a miniscule proportion of microorganisms present in the environment (GiovanNONI et al. 1990). Attempts to culture matforming cyanobacteria, which produce substantial biomass and represent principal primary producers of microbial mat communities have repeatedly failed, because the target organisms did not respond to standard growth media (ABED et al. 2003a, b; Richert et al. 2006; Foster et al. 2009). They succeeded, however, in attracting opportunistic organisms, which may be minor in the field but become suddenly dominant in response to the new conditions that favor their growth. While recent studies in microbial ecology focus on identifying dominant field bacterial populations using molecular tools, with the assumption that they are responsible for most bacterial activities, minor populations are often ignored.

Benthic cyanobacteria forming mats and microbialites in the lagoon of Tikehau Atoll, Tuamotu Archipelago, French Polynesia, have been investigated, using a polyphasic approach, with the emphasis on dominant populations distributed at different depths, from the surface down to $25 \mathrm{~m}$ (ABED et al. 2003a). Complementary to this study, we investigated here the diversity of autochthonous cyanobacteria of the same Lagoon that responded to cultivation under much higher concentrations of nutrients than in the field. The isolates were morphologically and genetically identified and characterized with respect to their pigmentation and potential to perform chromatic adaptation and nitrogen fixation. We postulate that these rare populations in the field represent cryptic diversity, which becomes important when the conditions change due to natural or man-made perturbations.

\section{Materials and Methods}

\section{Sampling site}

Tikehau is a semi-open atoll, with a central lagoon connected with the open ocean by a navigable channel and numerous shallow channels, called hoa. It is situated at the NW end of the Tuamotu Archipelago, in the most oligotrophic Pacific waters (CHARPY-
Roubaud et al. 1990). The lagoon covers an area of $400 \mathrm{~km}^{2}$ with an average depth of $25 \mathrm{~m}$. The climate is tropical, mild and uniform with a warmer rainy season from November to April and cooler dry season from May to October. Samples of cyanobacterial mats were collected in 1998 and 1999 by SCUBA diving (see also Sprachta et al. 2001 and AbEd et al. 2003b).

\section{Cultivation and strain identification}

Twelve uni-cyanobacterial cultures were obtained from strains originating from microbial mat inocula collected along a depth profile from the surface to a depth of ca $25 \mathrm{~m}$, after several transfers of single filaments and cell colonies to fresh media. All cultures were maintained in ASNIII medium (RIPPKA et al. 1979 ) at $20{ }^{\circ} \mathrm{C}$, at $30 \mu \mathrm{mol}$ photons. $\mathrm{m}^{-2} \cdot \mathrm{s}^{-1}$ (measured with a LICOR LI-185B quantum /radiometer/ photometer equipped with a LI-190SB quantum sensor) and under a light/dark cycle of 12/12 h. To prove the strains' ability to fix atmospheric nitrogen, each culture was grown in ASNIII medium without nitrogen for three months. Morphological observations were made using photomicroscope Axiovert and Axioplan, Zeiss equipped with phase-contrast and Nomarski Interference Contrast optical systems with the sample preparation described previously (PALIŃSKA et al. 1998). Morphological identification was done in accordance with traditional phycological (GEITLER 1932; KomÁrek \& ANAgnostidis 1999, 2005) and bacteriological (CASTENHOLZ 2001) determination manuals, while awaiting further confirmation by molecular sequencing. The cell size of ca 50 cells was measured for each strain. The variations in dimensions are provided as ranges.

\section{Extraction and analysis of carotenoids}

Two milliliters of each culture, incubated for two months at $30 \mu \mathrm{mol}$ photons. $\mathrm{m}^{-2} \cdot \mathrm{s}^{-1}$ (white light) were centrifuged for $10 \mathrm{~min}$ at $14000 \mathrm{rpm}$ (Eppendorf 5424). The pellet was immediately frozen in liquid nitrogen and lyophilized (Christ Alpha 1-4) in the dark. The lyophilized samples were homogenized with ice-cold $90 \%$ acetone in water, incubated at $4{ }^{\circ} \mathrm{C}$ for $2 \mathrm{~h}$, and finally centrifuged at $4500 \mathrm{~g}$ for $20 \mathrm{~min}$ at $5{ }^{\circ} \mathrm{C}$ to remove cellular particle debris. All steps were carried out under dim light. Pigments were separated using RP-HPLC (Merck-Hitachi, Darmstadt, Germany) as described in STON \& KosAKOWSKA (2000). Identification was performed by chromatography with commercially available standards. Phycobiliproteins were isolated according to GANTT et al (1972) In vivo absorption spectra and spectra of isolated phycobilisomes were measured at room temperature with a Hitachi 3000 spectrophotometer. The amount of total carotenoids after incubation under white light (at $30 \mu \mathrm{mol}$ photons. $\left.\mathrm{m}^{-2} \cdot \mathrm{s}^{-1}\right)$, red and green light were estimated according to Albertano (1991). 
Table 1. Oligonucleotide primers used for PCR and thermal cycling conditions for the PCR amplifications.

\begin{tabular}{|c|c|c|c|}
\hline Locus/Primers & Sequence (5` to3`) & Reaction conditions & Reference \\
\hline \multicolumn{4}{|l|}{$16 \mathrm{~S}$ rDNA } \\
\hline CYA 106F & CGGACGGGTGAGTAACGCGTTA & \multirow{2}{*}{$\begin{array}{l}1 \mathrm{x}\left(95^{\circ} \mathrm{C}, 5 \mathrm{~min}, 80^{\circ} \mathrm{C}, 1 \mathrm{~min}-\right. \\
\text { Hot start } 30 \mathrm{x}\left(94{ }^{\circ} \mathrm{C}, 1 \mathrm{~min}, 60\right. \\
\left.{ }^{\circ} \mathrm{C}, 1 \mathrm{~min} 72^{\circ} \mathrm{C}, 1 \mathrm{~min}\right)\end{array}$} & \multirow{2}{*}{$\begin{array}{l}\text { (NüBEL et al. } \\
1997 \text { ) }\end{array}$} \\
\hline CYA 781R & GACTACTGGGGTATCTAATCCCWTT & & \\
\hline \multicolumn{4}{|l|}{$\underline{n i f H}$} \\
\hline nifHF & TGYGAYCCNAARGCNGA & $\begin{array}{l}1 \mathrm{x}\left(94{ }^{\circ} \mathrm{C}, 5 \mathrm{~min}\right), 30 \mathrm{x}\left(93^{\circ} \mathrm{C},\right. \\
1.2 \mathrm{~min}, 50^{\circ} \mathrm{C}, 1 \mathrm{~min}, 70^{\circ} \mathrm{C}, \\
1.5 \mathrm{~min})\end{array}$ & $\begin{array}{l}\text { (ZEHR \& } \\
\text { MCREYNOLDS } \\
1989)\end{array}$ \\
\hline nifH $1 \mathrm{~F}$ & TACGGCAARGGTGGNATH & \multirow{2}{*}{$\begin{array}{l}96^{\circ} \mathrm{C} 4 \min , 30 x\left(94{ }^{\circ} \mathrm{C}, 1 \mathrm{~min}\right. \\
\left.55^{\circ} \mathrm{C}, 1 \mathrm{~min} ; 72^{\circ} \mathrm{C}, 2 \mathrm{~min}\right) 72 \\
{ }^{\circ} \mathrm{C}, 10 \min .\end{array}$} & \multirow[t]{2}{*}{$\begin{array}{l}\text { (Diallo et al } \\
2004 \text { ) }\end{array}$} \\
\hline nifH 1R & ATSGCCATCATYNTCRCCGGA & & \\
\hline \multicolumn{4}{|l|}{$c p c B A$} \\
\hline $\mathrm{PC} b \mathrm{~F}$ & GGCTGCTTGTTTACGCGACA & \multirow{2}{*}{$\begin{array}{l}4 \mathrm{x}\left(94{ }^{\circ} \mathrm{C}, 45 \mathrm{~s} ; 50^{\circ} \mathrm{C}, 1 \mathrm{~min}\right. \\
\left.72^{\circ} \mathrm{C}, 1 \mathrm{~min}\right), 25 \mathrm{x}\left(94^{\circ} \mathrm{C}, 45 \mathrm{~s}\right. \\
\left.55^{\circ} \mathrm{C}, 1 \mathrm{~min} ; 72{ }^{\circ} \mathrm{C}, 1 \mathrm{~min}\right)\end{array}$} & \multirow{2}{*}{$\begin{array}{l}\text { (NeILAN et al. } \\
1995 \text { ) }\end{array}$} \\
\hline $\mathrm{PC} a \mathrm{R}$ & CCAGTACCACCAGCAACTAA & & \\
\hline \multicolumn{4}{|l|}{ cpeBA } \\
\hline PE $\beta F$ & TAYCCTAACCGTCGYWTKGCTGC & \multirow{2}{*}{$\begin{array}{l}4 \mathrm{x}\left(94^{\circ} \mathrm{C}, 45 \mathrm{~s}, 50{ }^{\circ} \mathrm{C}, 1 \mathrm{~min},\right. \\
\left.72^{\circ} \mathrm{C}, 1 \mathrm{~min}\right), 25 \mathrm{x}\left(94^{\circ} \mathrm{C}, 45 \mathrm{~s},\right. \\
\left.55^{\circ} \mathrm{C}, 1 \mathrm{~min}, 72{ }^{\circ} \mathrm{C}, 1 \mathrm{~min}\right)\end{array}$} & \multirow[t]{2}{*}{$\begin{array}{l}\text { (BEARD et al. } \\
1999 \text { ) }\end{array}$} \\
\hline PE $\alpha R$ & GCRCGTTGRATRGAACCTTGTAC & & \\
\hline
\end{tabular}

Determination of chlorophyll-a, phycobiliproteins and complementary chromatic adaptation (CCA) Exponential-phase cells were used for the determination of phycobiliprotein absorption spectra. A 2-4 ml aliquot of culture was centrifuged at $14000 \mathrm{rpm}$ for 5 min at room temperature. The pellet was suspended in a buffer consisting of $50 \mathrm{mM}$ Tris/ $\mathrm{HCl}(\mathrm{pH} 8), 250$ $\mathrm{mM} \mathrm{NaCl}$ and $10 \mathrm{mM}$ EDTA and the cells were broken ultrasonically. In order to include chlorophyll-a peak in the spectrum, the broken cell suspension was incubated $30 \mathrm{~min}$ at $28{ }^{\circ} \mathrm{C}$ with $5 \%$ Triton, and finally centrifuged for $5 \mathrm{~min}$ at $14000 \mathrm{rpm}$ in an Eppendorf centrifuge to remove unbroken cells. The absorbance of the supernatant was measured from 400 to $750 \mathrm{~nm}$ at a Hitachi U 3000 spectrophotometer. Chlorophyll- $a$ and phycocyanin concentration were determined according to TANDEAU DE MARSAC (1979) and BENNETT \& BOGORAD (1973), respectively.

For CCA experiments each strain was cultured for six weeks separately under continuous light with fluorescent lamps (76 $\mu$ mol photons. $\left.\mathrm{m}^{-2} \cdot \mathrm{s}^{-1}\right)$. Chromatic illumination was provided by red or green plastic filters as described by TANDEAU DE MARSAC (1979) interposed between the culture vessels and the fluorescent tubes. Phycobiliprotein absorption spectra were then determined spectrophotometrically for each strain as described above.

\section{Nitrogenase activity measurements}

$1 \mathrm{ml}$ of unicellular and $1 \mathrm{~cm}^{2}$ of filamentous cyanobacterial culture was incubated in $65 \mathrm{ml}$ bottles fitted with septum with $15 \mathrm{ml}$ of filtered sea water $(\mathrm{DIN}<0.5 \mu \mathrm{M})$. For heterotrophic nitrogenase activity measurements, 3 replicates were incubated in the dark for $24 \mathrm{~h}$; afterwards $5 \mathrm{ml}$ of $\mathrm{C}_{2} \mathrm{H}_{2}$ was added to observe any heterotrophic $\mathrm{N}_{2}$ fixation after $12 \mathrm{~h}$ incubation in the dark. For phototrophic nitrogenase activity measurements, cultures were let 8 days in incubation chamber (day and night) to remove the DIN. Later on $5 \mathrm{ml}$ of $\mathrm{C}_{2} \mathrm{H}_{2}$ was added to 2 replicates and $\mathrm{C}_{2} \mathrm{H}_{4}$ production was measured after 4 days of incubation. The biomass of incubated benthic cyanobacteria was calculated from the chlorophyll- $a$ content. At the end of incubation with $\mathrm{C}_{2} \mathrm{H}_{2}$, the mat was dried using Whatman filter paper and frozen for later spectrophotometric analysis (CHARPy et al. 2007)

PCR amplification of $16 \mathrm{~S}$ rRNA, nifH, PC-IGS region and phycoerythrin $a$ and $b$ subunit gene fragments

DNA was extracted from $25 \mathrm{ml}$ of each culture using protocol of MARQUARDT \& PALIŃSKA (2007). DNA concentration was measured spectrophotometrically with the help of a LabelGuards cuvette (IMPLEN, Germany). Genomic DNA was used as a template in PCR amplifications with the primers specific to 


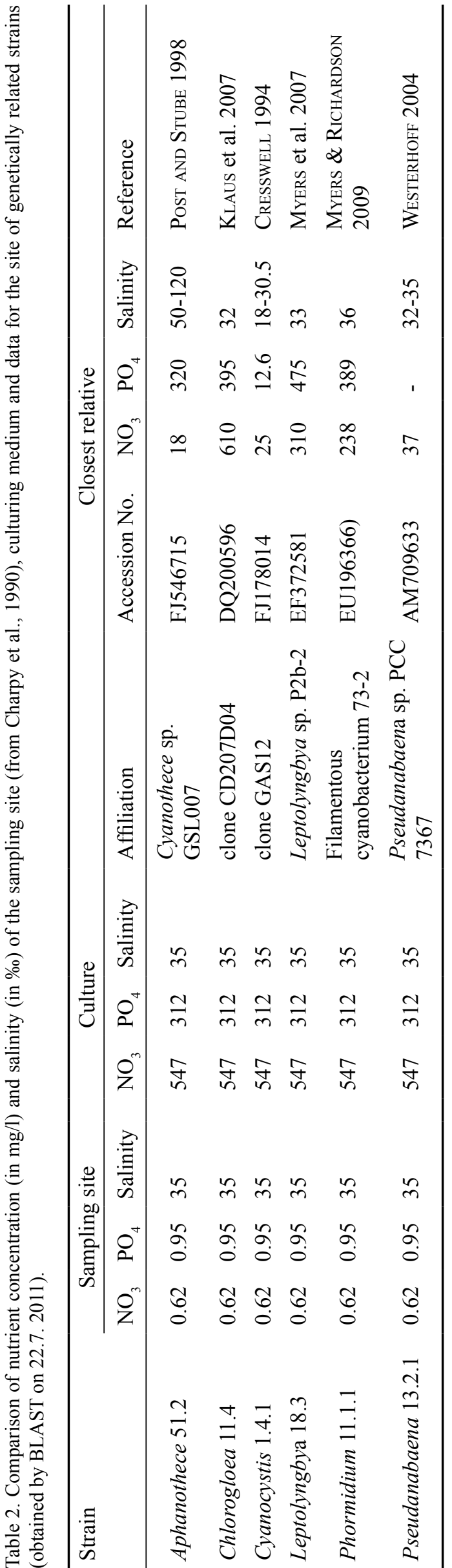

various genes (Table 1). PCR amplification reactions $(100 \mu$ l) contained: 1 x REDTaq PCR Buffer 200 $\mu \mathrm{M}$ of each deoxynucleotide $200 \mu \mathrm{g}$ BSA, $500 \mathrm{ng}$ of each oligonucleotide primer, $5 \mathrm{U}$ of RED Taq DNA polymerase (Sigma-Aldrich), and $5 \mu$ of DNA extract. The reactions were performed in an OmniGene thermal cycler (Hybaid). The reaction conditions for the PCR amplifications of the gene loci investigated are shown in Table 1. PCR products were analysed by agarose gel electrophoresis, appropriate bands (16S rRNA and PC-IGS regions) excised and DNA extracted using the QIAquick Gel Extraction Kit (Qiagen, Hilden, Germany). The amplified products of 16S rRNA and PC-IGS regions were commercially sequenced in both directions. The presence or absence of PCR products of nif $H$, and phycoerythrin $a$ and $b$ subunit gene fragments were only documented.

\section{Sequence analysis and phylogenetic affiliations}

Sequence alignment and phylogeny of 16S rRNA gene fragments obtained from the cultures were carried out using the ARB software (LuDwig et al. 1998) version 07.12.17prv and the official database (www.arb-home. de) for small subunit RNA sequences (ssu_jan04_corr_ opt.arb). Cyanobacterial gene sequences available from the GenBank were imported and aligned and the alignment was corrected manually. The phylogenetic trees were constructed by applying the three different methods integrated in the ARB software namely maximum likelihood, maximum parsimony and neighbor joining. The latter calculation was based on a matrix of evolutionary distances determined by using the Jukes-Cantor or Felsenstein equations and subject to bootstrap analysis (1000 replicates). The presented phylogenetic tree was calculated by maximum likelihood, based on long 16S rRNA gene sequences and the bootstrap values from 1000 trees are indicated as $\%$ at relevant nodes. The sequences were inserted into the pre-established tree using the parsimony ARB tool, while maintaining the overall tree topology without changes. The final tree was minimized for simplicity in presentation.

\section{Results}

Using transmitted light microscopy, 12 different cyanobacterial strains were identified; 3 in unicellular genera (Aphanothece NäGELI, Chlorogloea WILle, Cyanocystis BorzI) and 9 in filamentous, within 3 non-heterocystous genera (Leptolyngbya ANAGNOSTIDIS et Komárek, Phormidium KüzIng ex Gomont and Pseudanabaena LAUTERBORN). All strains grew only on the bottom of the flasks, consistent with their benthic origin. The strains showed clear variations in their morphological, physiological 
and genetic features (Table 2 and 3), but were mainly related to cyanobacteria from different ecosystems with high levels of nutrients (Table 2). The unicelluar strains (i.e 51.2, 11.4 and 1.4.1) were morphologically and phylogenetically different. Aphanothece-51.2 was characterized by ellipsoidal cells, dividing by binary fission in one plane and embedded in profuse unstructured slime (Fig. 1a). The closest sequence refers to the marine Cyanothece sp. (accession number DQ243690) from Qingdao, China (Fig. 2) and Cyanothece sp. GSL007 (FJ546715) from Great Salt Lake (Table 2). Chlorogloea-11.4 formed dense, irregular, gelatinous aggregates, consisting of spherical cells (Fig. 1b). Cells divided asynchronously in more than one plane, showing occasional cleavage type fission. Phylogenetic reconstrtuction (Fig. 2, Table 2) showed similarity with two sequences of cyanobacterial clones; one obtained from highly polluted Baltic Sea sediments (EDLUND \& JANSSON 2006) and the other from polluted coral microbial communities (KLAus et al. 2007). The closest sequence of cultured cyanobacteria belonged to Synechococcus ThN-P16 (98\%) from seagrass in East Africa (UKU et al. 2007). Cyanocystis1.4.1 formed colonies with cells embedded in asymmetric, club-shaped envelopes (Fig. 1c). Cells were variable in dimensions $(5-12.4 \mu \mathrm{m}$ in diameter) as a consequence of reproduction by multiple fission and dissemination of numerous small, spherical, non-motile baeocytes. The sequence of this strain clustered close to sequences from the genera Chroococcidiopsis, Pleurocapsa and Xenococcus (Fig. 2) but was closest to the environmental clone GAS12 (FJ178014, Table 2).

The strains 18.3, 22A and 51.1 were placed in the genus Leptolyngbya. They were all characterized by sheathed filaments containing single trichomes. Leptolyngbya-22A and 18.3 showed typical characteristics with trichomes consisting of isodiammetric or slightly longer than wide cells, constricted at cross walls (almost torulose) with rounded end cells. Leptolyngbya51.1 filaments had diffluent sheath and pale bluegreen trichomes gradually attenuated towards tips and cross walls were unconstricted or barely constricted. End cells were long, conical with a terminal gas vesicle cluster and with occasional gas vesicle clusters or granules at cross walls. The closest match of the Leptolyngbya strains 18.3, $22 \mathrm{~A}$ and 51.1 were the sequences of Phormidium persicinum, Phormidium sp. MBIC10025 and uncultured cyanobacterium clone $3 \mathrm{~b} / \mathrm{p} 2 \mathrm{e} 2$ refering to a marine, benthic cyanobacterium (BAUER et al. 2008), respectively (Fig. 2).

Four strains (B.3.1, 11.1.1, 11.2 and 11.3.2) isolated from two sites at $20 \mathrm{~m}$ depth were identified as representatives of the genus Phormidium (Fig. $1 \mathrm{~d}-\mathrm{g}$ ), following the classical definition of the genus Phormidium (Gomont 1892). These strains showed $100 \%$ 16S rRNA sequence similarity with each other (Fig. 2) with the closest cultured cyanobacterium belonging to a strain isolated from Dry Rock Reef in Florida (EU196366, Table 2). Our four Phormidium strains showed slight differences in color, cell size and cell proportions and significant difference with respect to the phycocyanine intrageneric spacer sequence (PCIGS). The filaments of all strains were curved and interwined with cells that were slightly constricted at the cross walls, isodiametric or slightly longer than wide and end cells were rounded.

Two strains (i.e. 13.2.1 and 72.1) isolated from mats growing at $20 \mathrm{~m}$ depth had the characteristic features of the genus Pseudanabaena. Both had deep constriction at cross-walls, cells distinctly separated, interconnected by a hyaline bridge (Figs $1 \mathrm{k}-\mathrm{m}$ ). They also exhibited clear distinction between centroplasma and chromatoplasma, suggesting parietal thylakoid arrangement. Both strains had cells longer than wide and end cells that were rounded, slightly apically attenuated. The cells of Pseudanabaena-72.1 were cylindrical frequently containing granulated inclusions. The 16S RNA of both strains fell next to sequences of the strain Pseudanabaena 63-1 from coral black-band disease in the Caribbean region (Voss et al. 2007) and Pseudanabaena PCC 7367 originating from a snail shell, intertidal zone in Mexico (RIPPKA \& Herdman 1992)(Fig. 1, Table 2).

\section{Amplification of nifH genes and rates of nitrogen fixation}

The amplification of nifH gene was successful in 8 out of the 12 strains, and their potential to fix atmospheric nitrogen was confirmed by growing them for three months under standard culture conditions in ASNIII medium without a nitrogen source (Table 3). Acetylene reduction assay revealed nitrogenase activity in the same strains (Table 4). No $\mathrm{C}_{2} \mathrm{H}_{4}$ production was measured after 24 hours incubation in the dark. From the unicellular species, Chlorogloea-11.4 and Cyanocystis-1.4.1 and from the filamentous types 

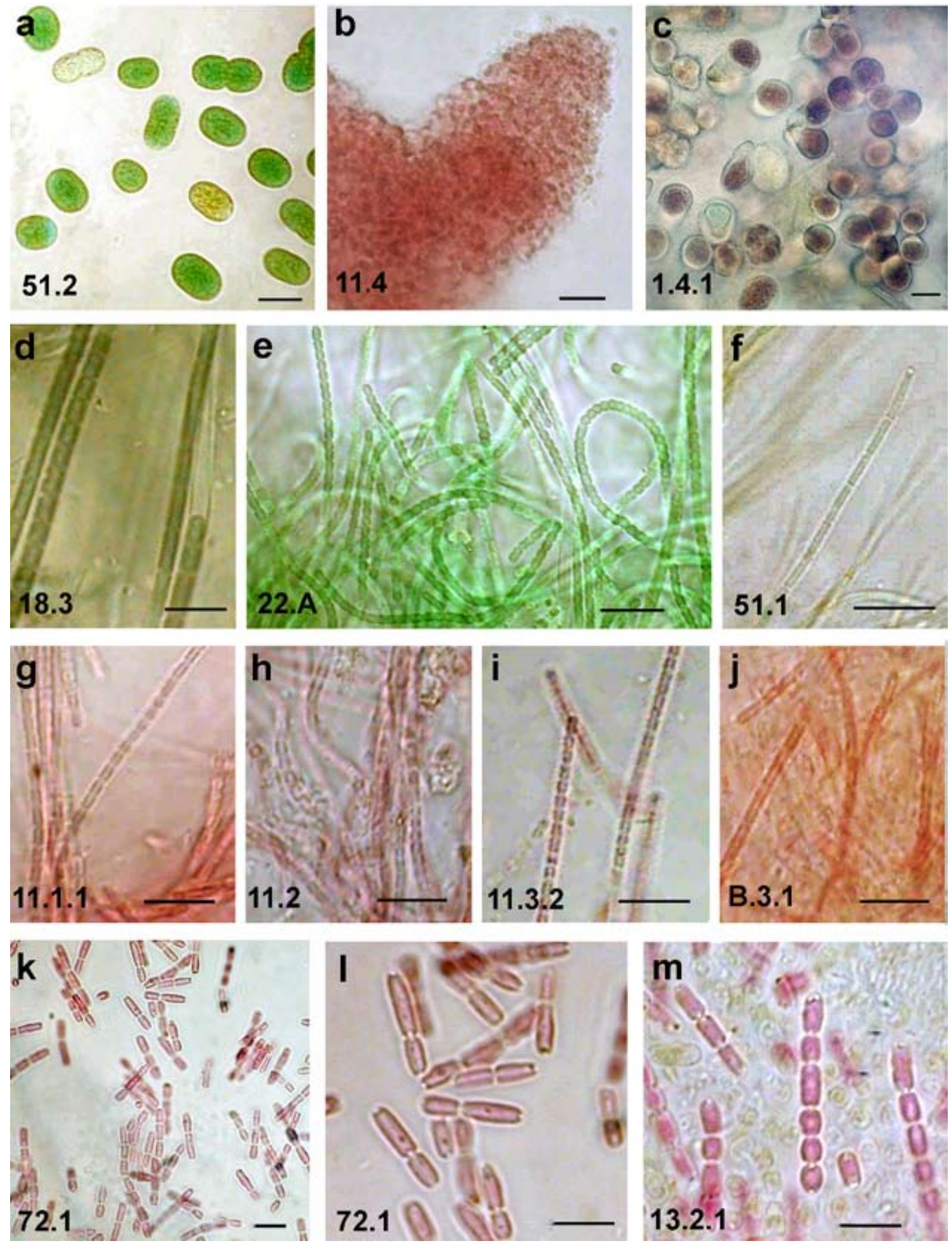

Fig. 1. Photomicrographs of cyanobacterial strains isolated from the mats in the benthos of the Lagoon of Tikehau Atoll, Tuamotu Archipelago, French Polynesia. Numbers in left corner represent strain numbers. Scale bar is $10 \mu \mathrm{m}$ long, except for strains 13.2.1 and 72.1 where it is $5 \mu \mathrm{m}$. The strains include coccoid cyanobacteria, Aphanothece (a ), Chlorogloea (b), and Cyanocystis (c); three sheathed and nonmotile filamentous strains of Leptolyngbya $(\mathrm{d}-\mathrm{f})$, four motile strains with diffluent sheats and slime production classified under the genus Phormidium $(\mathrm{g}-\mathrm{j})$ and two strains of Pseudanabaena $(\mathrm{k}-\mathrm{m})$. See text and Table 2 for description of properties of these strains by strain number. 


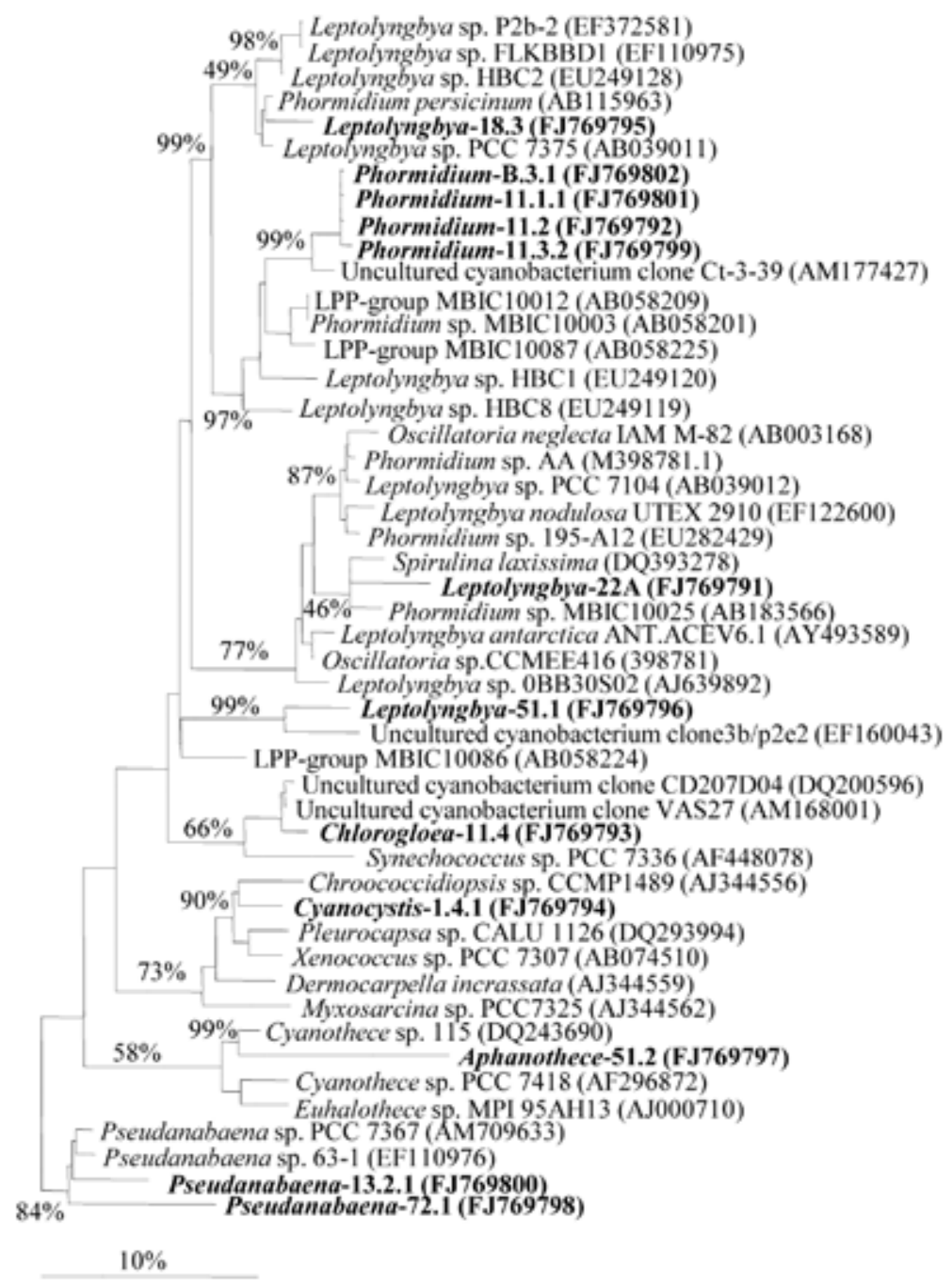

Fig. 2. 16S rRNA gene-based phylo-genetic reconstruction based on maxi-mum likelihood methods, showing the affiliations of cyanobacterial cultures ob-tained from Tikehau Lagoon. Accession numbers are indicated in brackets. Bootstrap values from 1000 trees are included and indicated as \% at relevant nodes The scale bar shows $10 \%$ sequence divergence. Sequences obtained in this study are marked bold.

only Phormidium-11.2 and Pseudanabaena-72.1 did not exhibit any nitrogenase activity. The nitrogen fixation rate ranged from 3.3 to 15.8 nmoles $\mathrm{N}_{2} \mu \mathrm{g}^{-1} \mathrm{Chl}-a \mathrm{~h}^{-1}$ with the highest rate measured in the culture of Phormidium 11.3.2.

\section{Pigment composition and complementary chromatic adaptation (CCA)}

Cyanobacteria isolated from the depth $\geq 15.5$ $\mathrm{m}$ contained PE genes and pigment, as detected by PCR and absorption spectroscopy, with the exception of Aphanothece-51.2, where neither the gene nor an absorption peak at $540 \mathrm{~nm}$ was detected (Table 3). The ability to undergo CCA was found only in two strains; Leptolyngbya 18.3 (isolated at $15.5 \mathrm{~m}$ depth) and Phormidium 11.1.1 (20 m depth). Carotenoid content in most strains (except Chlorogloea-11.4 and Leptolyngbya51.1), showed that the ratio of total carotenoids to chlorophyll-a increased after incubation under green light in comparison to the growth under white light. Most strains showed higher carotenoids/chlorophyll- $a$ ratio after incubation under red light than after the incubation under white and green light. The opposite results, i.e. a better utilization of green light was obtained in strains isolated from deeper water $(5.5-15.5 \mathrm{~m})$, which showed the carotenoid/chlorophyll-a ratio increased under white light rather that under green light.

HPLC analyses (Table 5), identified the major photoprotective and auxiliary carotenoid pigments; $\beta$-carotene, zeaxanthin, canthaxanthin, astaxanthin, xanthophylls, echinenone and 


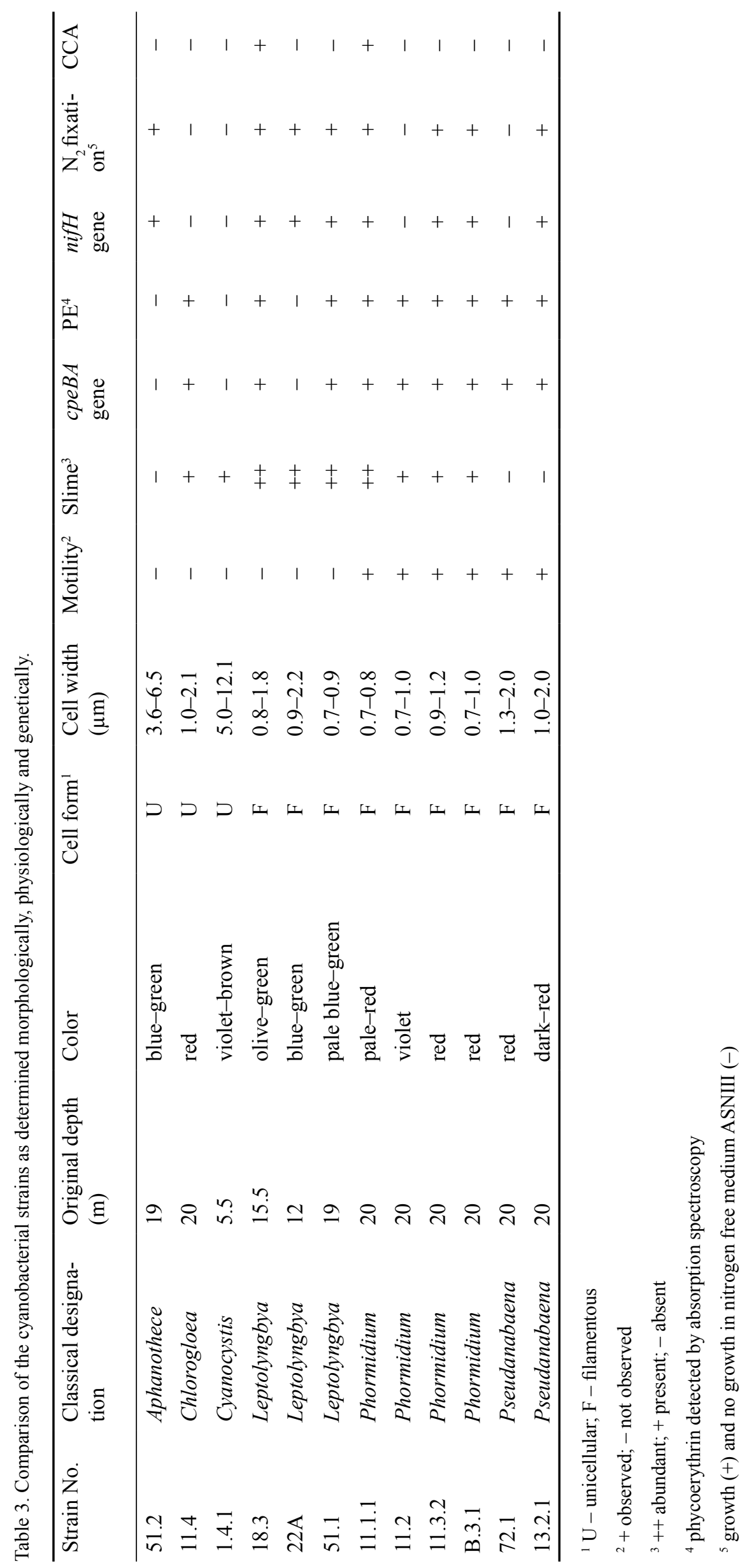


Table 4. Phototrophic nitrogenase activity measurements.

\begin{tabular}{llll}
\hline Strain & $\mathrm{nmoles} \mathrm{C}_{2} \mathrm{H}_{4} /$ & $\mu \mathrm{g} \mathrm{Chl}$ & $\mathrm{nmoles} \mathrm{C}_{2} \mathrm{H}_{4}$ \\
\cline { 2 - 4 } & $4 \mathrm{~h}$ incubation & incubated & $\mu \mathrm{g}^{-1} \cdot \mathrm{Chl}^{-1} \mathrm{~h}^{-1}$ \\
\hline Aphanothece 51.2 & 42.30 & 3.24 & 3.30 \\
Leptolyngbya 18.3 & 88.80 & 2.00 & 11.10 \\
Leptolyngbya $22 \mathrm{~A}$ & 59.30 & 3.68 & 4.00 \\
Leptolyngbya 51.1 & 55.80 & 3.44 & 4.10 \\
Phormidium 11.1.1 & 107.40 & 4.05 & 6.60 \\
Phormidium 11.3.2 & 177.60 & 2.80 & 15.80 \\
Phormidium B.3.1 & 60.20 & 4.00 & 3.80 \\
Pseudanabaena 13.2.1 & 37.20 & 2.65 & 3.50 \\
\hline
\end{tabular}

myxoxanthophyll. $\beta$-carotene and zeaxanthin were present in all isolates, however, $\beta$-carotene quantitatively dominated. Myxoxanthophyll occurred in all tested strains, except in the strain Leptolyngbya-18.3. Canthaxanthin was found only in Aphanothece-51.2 and Astaxanthin in Pseudanabaena-72.1. The molar carotenoid/ chlorophyll $a$ ratios werehighly variable from strain to strain, depending on the individual physiological conditions and the degree of light adaptation. Therefore, two to three-fold differences in the pigment ratios could usually be detected. Some isolates showed always higher concentrations of a specific pigment compared to other strains. For example, the strains Aphanothece-51.1 and Pseudanabaena-72.1 exhibited particularly high concentrations of zeaxanthin.

\section{Discussion}

The cyanobacteria that grew in our cultures were entirely different from those that dominated in inocula and presented a different picture from the one obtained from the sampling sites (ABED et al. 2003). While mats in the field were dominated by cyanobacterial populations of Phormidium laysanense, $P$. hendersonii, $P$. crosbyanum, Symploca hydnoides, Hydrocoleum coccineum, H. cantharidosmum and Spirulina subsalsa, the enrichment cultivation recruited minute filamentous and unicellular cyanobacteria. This could be attributed, among other factors, to the clear difference in nutrient concentrations in the field and in the provided medium. While the ammonium and phosphate concentrations were 0.62 and $0.95 \mathrm{mg} . \mathrm{l}^{-1}$ in the field (CHARPY-Roubaud et al. 1990), they reached 547 and $312 \mathrm{mg} \cdot \mathrm{l}^{-1}$ in the culture medium, respectively (see Table 2 ). In the process of matching our sequences with their closest genetic relations listed in the GenBank, we found a general agreement regarding the habitat, including association with elevated nutrient levels (Table 2 and Fig. 1). For example, Chlorogloea strain-11.4 was related to the clone CD207D04 obtained from an environment that had 610 and $395 \mathrm{mg} \cdot \mathrm{l}^{-1}$ of ammonium and phosphate, respectively and also shared $99 \%$ sequence similarity with the clone VAS27, which appeared and increased in abundance after dredging in polluted Baltic Sea sediment (EDLUnd \& JANSEN 2006). The same signature was detected in bacterial communities along a gradient from pristine to polluted conditions, expressed especially in shallow coastal waters (KLAus et al. 2007). Our Phormidium strains were affiliated to sequences of cyanobacteria obtained form photosynthetic coral reef sediments while our Leptolyngbya strain 18.3 was related to cyanobacterial species associated with black band diseased corals where nutrient concentrations were also high (Table 2). The cultured strains showed variability in their ability to fix nitrogen, in pigment composition and the capacity for complementary chromatic adaptation. Although these properties were also observed in field dominant cyanobacteria, they may still help the cultured cyanobacteria to replace dominant taxa in different niches and at different depths, light regimes and nutrient conditions (REZNICK et al. 2002).

Cyanobacteria with extremely thinfilaments have been generally observed to overtake dominant populations following catastrophic impacts and natural perturbations (ABED et al. 2001; EDLUND \& 
Table 5. Carotenoid and chlorophyll- $a$ concentrations (nmol.g ${ }^{-1}$ dry weight) in different strains [(Ech) Echinenone, (Myx) Myxoxanthophyll, (Zea) Zeaxanthin, ( $\beta-\mathrm{Ca}) \beta$-Carotene, (Cat) Cathaxanthin, (Ast) Astaxanthin].

\begin{tabular}{lllllllll}
\hline Strain & Depth & Chl- $a$ & Ech & Myx & Zea & $\beta-$ Ca & Cat & Ast \\
\hline Aphanothece 51.2* & 19 & 873.7 & 272.3 & 579.5 & 19.0 & 352.2 & 18.4 & - \\
Chlorogloea 11.4 & 20 & 12.5 & - & 62.5 & 7.1 & 101.3 & - & - \\
Cyanocystis 1.4.1 & 5.5 & 564.7 & - & 31.8 & 174.1 & 119.1 & - & - \\
Leptolyngbya 18.3 & 15.5 & 1006.2 & - & - & 194.8 & 187.3 & - & - \\
Leptolyngbya 22A & 12 & 404.7 & - & 58.9 & 80.6 & 145.9 & - & - \\
Leptolyngbya 51.1 & 19 & 1774.7 & 42.0 & 140.2 & 461.2 & 490.9 & - & - \\
Phormidium 11.1.1 & 20 & 401.5 & - & 42.4 & 106.8 & 7.6 & - & - \\
Phormidium 11.2 & 20 & 929.1 & - & 45.9 & 190.4 & 611.0 & - & - \\
Phormidium 11.3.2 & 20 & 807.9 & - & 51.6 & 23.3 & 331.6 & - & - \\
Phormidium B.3.1 & 20 & 534.9 & - & 73.1 & 114.3 & 219.8 & - & - \\
Pseudanabaena $72.1 * *$ & 20 & 3439.6 & - & 126.4 & 538.0 & 543.1 & - & 1134.9 \\
Pseudanabaena 13.2 .1 & 20 & 1038.0 & - & 159.2 & 222.6 & 243.0 & - & - \\
\hline
\end{tabular}

JANSEN 2006; KLAUS et al. 2007) and thus may be considered opportunistic. These populations are referred to as " $\mathrm{r}$-selected species" according to the $r / k$ selection theory, because they have a high growth rate and typically produce many offsprings, each has a relatively low probability of survival to adulthood (REZNicK et al. 2002). The field populations can be considered as the " $k$-selected" species because they are often strong competitors in crowded niches and invest heavily in fewer offsprings that can survive to adulthood. It should be, however, noted that not all cyanobacteria with narrow filaments are opportunistic. For instance, the narrow filaments of Phormidium hendersonii and $P$. crosbyanum produced frequently occurring populations in the field of the Tikehau lagoon, where stable oligotrophic settings are prevalent (ABED et al. 2003b). These taxa are different from Leptolyngbya-like organisms cultured from the same environment. Nutrient release is common in coastal environments; periodic storms contribute to sediment erosion and nutrient release at a scale commensurate with the impact, whereas small scale concentrations of nutrients accompany decomposing carcasses. Such events offer transient opportunities to fast responding microorganisms, which are otherwise present in the environment in low numbers. Indeed, a recent study demonstrated that subdominant species representing less than $0.3 \%$ of the total cell number, contributed to more than $40 \%$ of the ammonium uptake and $70 \%$ of the carbon uptake in Lake Cadagno (Musat et al.
2008), hinting to the ecological and functional importance of field minor populations. The occurrences of similar and/or related taxa were consistently observed in marine, coastal and nutrient rich environments (e.g. BAUER et al. 2008). For example, the transfer of a microbial mat from the field and its maintainance under laboratory conditions for 1.5 year (ABED et al. 2001) and the exposure of a microbial mat to oil pollution (ABED et al. 2002), both showed a dramatic shift in the cyanobacterial community in the favor of thin filamentous cyanobacteria. Among our isolates, six have closest genetic similarity to cyanobacteria associatecd with microflora of the "black band disease" (MYers et al. 2007; Voss et al. 2007; Klaus et al. 2007; Myers \& Richardson $2009)$ and two more with "white plague disease" in corals (Suagawa et al. 2009). These authors might not have detected the causes but rather the consequences of the coral disease. The diseased and decomposed coral tissue may have served as a local nutrient source, an assumption consistent with our findings.

The identification of thin filamentous opportunistic cyanobacteria is often hampered by their very small size and inconspicuous structure. For instance, the distinction between the genera Leptolyngbya and Phormidium is not clear either by morphotypic or genotypic characterization. Gomont (1892) and Geitler (1932) included taxa with narrow trichomes within Phormidium genus, whereas these were transferred by KOMÁREK \& 
Anagnostidis (2005) into a newly established genus Leptolyngbya (ANAGNOSTIDIS \& KoMÁREK 1988). Both genera are polyphyletic and require further revision (CASTENHOLZ 2001; MARQUARDT $\&$ PALINSKa 2007). The sequence similarity among our strains with narrow trichomes ranged between 8 and $11 \%$. Therefore, we separated our strains with narrow trichomes into Leptolyngbya and Phormidium on the basis of trichome motility, with immotile strains placed in Leptolyngbya, following the recommendation of CASTENHOLZ (2001).

The four strains we have identified as Phormidium were identical with respect to $16 \mathrm{~S}$ rRNA gene, but they showed some morphological, physiological and genetic differences. While their 16S rRNA sequences were identical, they differed from each other by $15-22 \%$ with respect to phycocyanin coding gene fragment (CpcBAIGS). In addition, the nifH gene was present in three out of four strains (B.3.1, 11.1.1, and 11.3.2 but not 11.2) whereas only one of the strains (11.1.1) exhibited chromatic adaptation. These strains were also phenotypically distinct, showing different slime production and significant quantitative differences in the composition of carotenoids. These differences are most probably adaptations to the environment where the organisms spread and show intra-specific diversity. Using molecular methods in case of Phormidium, we were unable to decide at what sequence similarity to define a species and how to incorporate its ecology into species definitions. Inside the generic cluster of Phormidium there exist numerous stable eco- and morphotypes, but also numerous intermediate populations. Hypotheses about the impossibility to identify taxa on a specific level ("only strains exist") support this opinion. In spite of it, many important morphologically and eco-physiologically stable units exist in nature, and they occur repeatedly in distant localities under similar ecological situations. They are important for ecologists and thus the traditional morphological concept of species is still commonly used in ecological studies. These findings demonstrate the resolution limits of the 16S rRNA gene as a single taxonomic marker. Our Phormidium strains were in respect of $16 \mathrm{~S}$ rRNA sequences identical, however morphologically and physiologically different. Further, we have found big genetic differences in PC-IGS fragments, therefore all four isolates were treated during our studies as separated strains. The conventional $97 \%$ similarity index with respect to bacterial species separation using this gene (Stackebradt \& Goebel 1994) has been recently revised upward to $98 \%$ (STACKEBRANDT \& EBERS 2006), however an inclusion of analysis of additional genes is needed in determination of cyanobacteria. Further revision took place in IAC meeting in Ceske Budejovice 2010, were it was postulated not to accept strict percentage limits in species definition.

Summarizing, our study on cryptic diversity of cyanobacteria from Tikehau Lagoon shows the potential of these populations to fix atmospheric nitrogen, perform chromatic adaptation and use different light intensities and qualities owing to the diverse pigments (carotenoids and phycobilins). We could demonstrate that the cultivation approach result in taking over the dominance of those populations that are present but cryptic in nature. Thus, today's minor community members can be tomorrow's main players in microbial ecosystems. Further, they can indicate eutrophication processes, maybe even faster, than it will be visible on macrofauna or macroflora.

\section{Acknowledgment}

The work was supported by the DFG grant PA842/9-1 (KP). Max-Plank-Institute for Marine Microbiology and Hansewissenschaftskolleg (HWK) are thanked for their research support (RA). Alexander-von-Humboldt Foundation, Bad Godesberg and Hanse Institute for Advanced Studies, Delmenhorst, Germany supported international and interdisciplinary cooperation (SG, RA).

\section{References}

Abed, R.M.M \& Garcia-Pichel, F. (2001): Longterm compositional changes after transplant in a microbial mat cyanobacterial community revealed using a polyphasic approach. Environ. Microbiol. 3: 53-62.

Abed, R.M.M.; Golubic, S.; Garcia-Pichel, F.; CAmoin, G. \& Sprachta, S. (2003a): Characterization of microbialite-forming cyanobacteria in a tropical lagoon: Tikehau Atoll, Tuamotu, French Polynesia. - J. Phycol. 39: 862-873.

Abed, R.M.M.; Golubic, S.; Garcia-Pichel, F.; CAmoin, G. \& SeOng-Joo, L. (2003b): Identity and speciation in marine benthic cyanobacteria: the Phormidium complex. - Algological Studies 109: 35-56.

Abed, R.M.M.; SAfi, N.M.D.; KöSTER, J.; De BeER, D.; El-NAHHAL, Y.; RUllKötTER, J. \& GarCia-PiChEL, 
F. (2002): Microbial diversity of a heavily polluted microbial mat and its community changes following degradation of petroleum compounds. - Appl. Environ. Microbiol. 68: 1674-1683.

Albertano, P. (1991): Effects of monochromatic lights on four species of Leptolyngbya. - Algological Studies 64: 199-214.

Amann, R.I.; Ludwig, W. \& Schleifer, K.H. (1995): Phylogenetic identification and in situ detection of individual microbial cells without cultivation. - Microbiol. Rev. 59 :143-169.

Anagnostidis, K. \& KomareK, J. (1988): Modern Approach to the classification system of Cyanophytes 3 - Oscillatoriales. - Algological Studies 50-53: 327-472.

Bauer, K.; Diez, B.; Lugomela, C., Seppala, S., Borg, A.J. \& Bergman, B. (2008): Variability in benthic diazotrophy and cyanobacterial diversity in a tropical intertidal lagoon. - FEMS Microbiol. Ecol. 63: 205-221.

Beard, S.J.; Handley, P.K.; Hayes, P.K. \& Walsby, A.E. (1999): The diversity of gas vesicle genes in Planktothrix rubescens from Lake Zürich. Microbiology 145: 2757-2768.

Bennett, A. \& Bogorad, L. (1973): Complementary chromatic adaptation in a filamentous bluegreen alga. - J. Cell Biol. 58: 419-435.

Castenholz, R.W. (2001): General characteristics of the cyanobacteria. - In Boone, D.R. \& CASTenholz, R. W. (eds): Bergey's Manual of Systematic Bacteriology. - pp. 474-487, Springer, New York.

Charpy, L.; Alliod, R.; Rodier, M. \& Golubic, S. (2007): Benthic nitrogen fixation in the SW New Caledonia lagoon. - Aquat. Microbial Ecol. 47: 73-81

Charpy-Roubaud, C.J.; Charpy, L. \& Cremoux, J.L. (1990): Nutrient budget of the lagoonal waters in an open central South Pacific atoll (Tikehau, Tuamotu, French Polynesia).-Marine Biol. 107: 67-73.

Cresswell, G. (1994): Nutrient enrichment of the Sydney continental shelf. - Australian J. Marine Freshwater Res. 45: 677-691

Delong, E F. \& Pace, N.R. (2001): Environmental diversity of Bacteria and Archaea. - Syst. Biol. 50: 470-478.

Diallo, D.M.; Willems, A.; Vloemans, N.; Cousin, S.; Vandekerckhove, T.T.; De lajudie, P.; Neyra, M.; Vyverman, W.; Gillis, M. \& VAN Der GUCht, K. (2004): Polymerase chain reaction denaturing gradient gel electrophoresis analysis of the N2fixing bacterial diversity in soil under Acacia tortilis ssp. raddiana and Balanites aegyptica in the dryland part of Senegal. - Environ. Microbiol. 64: 400-415.

Edlund, A. \& JAnsson, J.K. (2006): Changes in active bacterial communities before and after dredging of highly polluted Baltic Sea sediments. - Appl. Environ. Microbiol. 72: 6800-6807.

FEwer, D.; FriedL, T. \& BüdEL, B. (2002): Chroococcidiopsis and heterocyst differentiating cyanobacteria are each other's closest living relatives. - Mol. Phylogenet. Evol. 23: 82-90.

Foster, J.S.; Green, S.J.; Ahrendt, S.R.; Golubic, S.; Reid, R.P.; Hetherington, K.L. \& Bebout, L. (2009): Molecular and morphological characterization of cyanobacterial diversity in the stromatolites of Highborne Cay, Bahamas. - ISME 3: 573-587.

Gantr, E. \& Lipschultz, C.A. (1972): Phycobilisomes of Porphyridium cruentum.I Isolation. - J. Cell Biol. 54: 313-324.

Gast, G J. Syllabus for the Reef Care Curaçao Workshop on Nutrient Pollution, Curaçao, 23 Oct 1998. http://www.reefcare.org

Geitler, L. (1932). Cyanophyceae.- In: Kolkwitz, R. (ed.): Rabenhorst's Kryptogamenflora von Deutschland, Österreich und der Schweiz 14. - 1196 pp., Akademischer Verlag, Leipzig.

Gomont, M.M. (1892): Monographie des Oscillariées. -Ann. Sci. Nat. Bot. 15:263-368 \& 16: 91-264. Paris.

Giovannoni, S.J.; Delong, E.F.; Schmidt, T.M. \& Pace, N.R. (1990): Tangenital flow filtration and preliminary phylogenetic analysis of marine picoplankton. - Appl. Environ. Microbiol. 56: 2572-2575.

Golubic, S.; Seong-Joo, L. \& Browne, K.M. (2000): Cyanobacteria: architects of sedimentary structures. - In: Riding, R.W. \& AwrAmiK, S.M. (eds): Microbial Sediments. - pp. 57-67, Springer-Verlag, Berlin-Heidelberg.

Gresswell, G. (1994): Nutrient enrichment of the Sydney continental shelf. - Aust. J. Mar. Fresh. Res. 45: 677-691.

Grossman, A.R.; Schaefe, M.R.; Chiang, G.G. \& Collier, J.L. (1993): The Phycobilisome, a light-harvesting complex responsive to environmental conditions. - Micobiol. Rev. 57: 725-749.

Klaus, J.S.; Janse, I.; Heikoop, J.M.; SAnFord, R.A. \& Fouke, B.W. (2007): Coral microbial communities, zooxanthellae and mucus along gradients of seawater depth and coastal pollution. - Environ. Microbiol. 9: 1291-1305

KomÁreK, J. \& Anagnostidis, K. (1999): Cyanoprokaryota, 1. Teil: Chroococcales. - In: Ettl, H.; Gärtner, G.; Heynig, G. \& Mollenhauer, D. (eds): Süßwasserflora von Mitteleuropa 19/1. - 548 pp., Gustav Fischer Verlag, Jena.

KomÁreK, J. \& AnAgnostidis, K. (2005): Cyanoprokaryota 2. Teil: Oscillatoriales. - In Büdel, B.; GÄrtner, G.; Krienitz,L. \& Schlager, 
M. (eds): Süßwasserflora von Mitteleuropa 19/2. - 759 pp., Elsevier, München.

Laurent, D.; Kerbrat, A-S.; Darius, H.T.; Girard, E.; Golubic, S.; Bennoit, E.; Sauviat, M.P.; Chinain, M.; Molgo, J. \& Paullac, S. (2008): Are cyanobacteria involved in Ciguatera Fish Poisoning outbreaks in New Caledonia? Harmful Algae 7: 827-838.

Litter, M.; Litter, D.; Lapointe, B. \& Barile, P. (2006): Toxic Cyanobacteria (blue green algae) associated with groundwater conduits in the Bahamas. - Coral Reefs 25: 186.

Ludwig, W.; Strunk, O.; Klugbauer, S.; Klugbauer, N.; WeizenEgGer, M.; Neumaier, J.; BACHLEITNER, M. \& SchleIFER, K.H. (1998): Bacterial phylogenybased on comparative sequence analysis. - Electrophoresis 19: 554-568

Marquardt, J. \& PalinsKa, K.A. (2007): Genotypic and phenotypic diversity of cyanobacteria assigned to the genus Phormidium (Oscillatoriales) from different habitats and geographical sites. -Arch. Microbiol. 187: 397-413.

Montojo, U.M. (1992): Proceedings of the SEAFDEC Seminar on Fishery Resources in the South China Sea, Area III

Myers, J.L.; SeKar, R. \& Richardson, L.L. (2007): Molecular detection and ecological significance of the cyanobacterial genera Geitlerinema and Leptolyngbya in black band disease of corals. Appl. Environ. Microbiol. 73: 5173-5182.

Myers, J.L. \& Richardson, L.L. (2009): Adaptation of cyanobacteria to the sulphide rich microenvironment of black band disease of coral. - FEMS Microbiol. Eco.1 67: 242-251.

NeIlan, B.A.; Jacobs, D. \& Goodman, A.E. (1995): Genetic diversity and phylogeny of toxic cyanobacteria determined by DNA polymorphisms within the phycocyanin locus. - Appl. Environ. Microbiol. 61: 3875-3883.

Nübel, U.; Garcia-Pichel, F. \& Muyzer, G. (1997): PCR primers to amplify $16 \mathrm{~S}$ rRNA $\mathrm{g}$ e $\mathrm{n}$ e $\mathrm{s}$ from cyanobacteria. - Appl. Environ. Microbiol. 63: 3327-3332.

Palińska, K.A.; Krumbein, W.E.; Schlemminger, U. (1998): Ultramorphological studies on Spirulina sp. - Bot. Ma.r 41: 349-355.

Paul, V.J.; Thacker, R.W.; Banks, K. \& Golubic, S. (2005): Benthic cyanobacterial bloom impact the reefs of South Florida (Broward Country USA). - Coral Reefs 24: 693-697.

Post, F.J. \& Stube J.C. (1998): A microcosm study of nitrogen utilization in the Great Salt Lake, Utah. - Hydrobiol. 55: 89-100.

Ravenschlag, K.; Sahm, K.; Pernthaler, J. \& Amann, R. (1999): High bacterial diversity in permanently cold marine sediments. - Appl. Environ. Microbiol. 65: 3982-3989.

Reznick, D.; Bryant, M.J. \& Bashey, F. (2002): R- and $\mathrm{k}$ selection revisited: the role of population regulation in life-history evolution. - Ecology 83: $1509-1520$.

Richert, L.; Golubic, S.; De le gue, R.; Herve, A. \& PAYri, C. (2006): Cyanobacterial populations that build 'kopara' microbial mats in Rangiroa, Tuamotu Archipelago, French Polynesia. - Eur. J. Phycol. 41: 259-279.

RipPKa, R.; Deruelles, J.; Waterbury, J. B.; Herdman, M. \& STANIER, R.Y.(1979): Generic assignments, strain histories and properties of pure cultures of cyanobacteria. - J. Gen. Microbiol. 111: 1-61.

Rippka, R. \& Herdman, M. (1992): Pasteur Culture Collection of CyanobacterialStrains. Axenic Culture. Vol. 1. Paris: Institut Pasteur.

Sprachta, S.; Camoin, G. ; Golubic, S. \& Le CampionALDUMARD, T. (2001): Microbialites in a modern lagoonal environment: nature and distribution, Tikehau atoll (French Polynesia). Palaeogeogr. Palaeoclimatol. Palaeoecol. 175: 103-124.

Stackebrandt, E. \& Goebel, B.M. (1994): Taxonomic note: A place for DNA-DNA reassociation and 16S rRNA sequence analysis in the present species definition in bacteriology. - Int. J. Syst. Bacteriol. 44: 846-849.

Stackebrandt, E. \& Ebers, J. (2006): Taxonomic parameters revisited: tarnished gold standards. - Microbiol. Today 33: 152-55.

Sunagawa, S.; DeSantis, T.Z.; Piceno, Y.M.; Brodie, E.L.; DeSalvo, M.K.; Voolstra, C.R.; Weil, E.; Andersen, G.L. \& Medina, M. (2009): Bacterial diversity and White Plague Disease-associated community changes in the Caribbean coral Montastraea faveolata. - ISME 3: 512-521

Ston, J. \& Kosakowska, A. (2000): Qualitative and quantitative analysis of Baltic phytoplankton pigments. - Oceanologia 42: 449-471.

TANDEAU DE MARSAC, N. (1977): Occurrence and nature of chromatic adaptation in Cyanobacteria. - J. Bacteriol. 130: 82-91.

Uku, J.; Bjork, M.; Bergman, B. \& Diez, B. (2007): Characterization and comparison of prokaryotic epiphytes associated with three East African seagrasses. - J. Phycol. 43: 768-779.

Voss, J.D.; Mills, D.K.; Myers, J.L.; Remily, E.R. \& RichARDSON, L.L. (2007): Black band disease microbial community variation on corals in three regions of the wider Caribbean. - Microb. Ecol. 54: 730-739.

Westerhoff, P. (2004) Drinking water quality in the US-Mexico border region project Arizona State University, University of Utah, Final Report, pp.1-72.

Wilmotte, A. \& Herdman, M. (2001): Phylogenetic relationships among the cyanobacteria based on 16S rRNA sequences. - In: GARRITY, G.M. (ed.): Bergey's Manual of Systematic Bacteriology, 
$2^{\text {nd }}$ Edition. - 487-493 pp., Springer-Verlag, New York.

ZEHR, J.P. \& McreynoldS, L.A. (1989): Use of degenerate oligonucleotides for amplification of the nifH gene from the marine cyanobacterium Trichodesmium spp. - Appl. Environ. Microbiol. 55: 2522-2526.

(C) Czech Phycological Society (2012)

Received March 1, 2011

Accepted August 8, 2011 